\title{
The Moderating Role of Family Control on the Relationship between Audit Committee Financial Expertise and Earnings Management
}

\author{
Yousef Abu Siam ${ }^{1}$, Mohammed Idris ${ }^{1} \&$ Saleh Al- Okdeh ${ }^{1}$ \\ ${ }^{1}$ Department of Accounting, Faculty of Business, Applied Science Private University, Amman, Jordan \\ Correspondence: Mohammed Idris, Department of Accounting, Applied Science Private University, Jordan. \\ E-mail: m.idris@asu.edu.jo
}

Received: September 29, 2018

doi:10.5539/ijbm.v13n12p31

\author{
Accepted: October 15, 2018 \\ Online Published: November 12, 2018 \\ URL: https://doi.org/10.5539/ijbm.v13n12p31
}

\begin{abstract}
The current study offers empirical evidence on the way the family ownership moderates the association that exists between the financial experience of the audit committee and earnings management based on a sample of 44 manufacturing firms that are registered with the Amman Stock Exchange (ASE) from 2012 to 2016. From the results of the study, there is a significant negative association between the financial experience of the audit committee and earnings management. In addition, the study shows a positive interaction of the financial experience of the audit committee and the family ownership on earnings management. This indicates that an increase in the percentage of audit committee members having financial expertise, in order to restrict earnings management, is less likely to be influential in the case of family controlled firms. These results have implications for policy makers and regulatory bodies in Jordan since they highlight the need to improve the good corporate governance practices and attempt to constrain the incidence of earnings management in Jordanian firms.
\end{abstract}

Keywords: audit committee financial expertise, earnings management, family ownership, Jordan

\section{Introduction}

Audit committee (hereafter, AC) is one of the main components in the structure of corporate governance that assists in controlling and monitoring managements (Arun et al., 2015). It is regarded as a sub-committee in the governing body that enables the official communication among the governing body, the external and internal auditors. According to Rezaee (2005), the AC guards the company's financial integrity and can enhance the financial reporting quality through reviews of the financial reports on behalf of the board.

The regulators have become interested to know the efficiency of the ACs in monitoring the financial reporting of companies in response to the key accounting scandals in America. One of the main reforms to enhance the effectiveness of the $\mathrm{AC}$ quality focuses on the financial expertise of $\mathrm{AC}$ members, where many studies tend to assert that the $\mathrm{AC}$ financial expertise (hereafter, $\mathrm{ACFE}$ ) which is one of the most crucial factors influencing the AC's effectiveness (Abbott et al., 2004; Siam et al., 2015; Chen and Komal, 2018). Moreover, in 1999, there was a recommendation from the Blue Ribbon Committee that $\mathrm{AC}$ members are ought to be financially knowledgeable of accounting or financial management. Additionally, the Sarbanes-Oxley Act (2002) requires that the AC should have member who is a financial expert. Moreover, previous empirical studies indicate that the financial experience of $\mathrm{AC}$ members plays a significant role in restricting earnings management (hereafter, EM) practices (e.g., Agrawal \& Chadha, 2005). Therefore, there are requirements in a large number of countries for some members of the AC to have financial and accounting expertise (Zalata et al., 2018).

Previous studies indicate that ownership styles vary significantly across economies such as Asian countries (Hashim, 2011); the vast majority of publicly traded firms are concentrated and predominantly controlled by a relatively small number of individuals, and families (Porta et al., 1999). According to Jaggi et al. (2009), agency conflicts between majority and minority owners might be more evident in family-controlled firms, where majority shareholders have a great motivation to expropriate wealth as they seek personal benefits at the expense of minority shareholders.

Consequently, the involvement of corporate governance mechanism such as ACFE to provide optimal monitoring is needed in order to diminish any agency conflicts which arise in family-controlled firms and reduce EM practices to protect minority shareholders' wealth from being expropriated. 
The results of this research will add value to existing literature as many Arab companies are owned and controlled by family groups such as Jordan. Thus, the findings of this research can be applied to many countries which share distinctive characteristics of the legal environment, ownership concentration, and family businesses (Wang, 2006). In addition, this study contributes to the literature through providing new insight and understanding about the relationship between ACFE and EM which is influenced by the family ownership control (hereafter, FOC) in the Jordanian context.

The research is organized into several sections as follows: a review of the literature and development of research hypothesis on ACFE, FOC, and EM is provided in the following section. Then, the sample data and methodology is presented. Finally, test results, findings and conclusions are summarized and discussed.

\section{Literature Review and Hypothesis Development}

\subsection{Impact of FOC on the Relationship between ACFE and EM}

Lin et al. (2009) posits that the AC's major duty is overseeing the companies' procedures of auditing and financial reporting and, therefore, the members ought to have adequate knowledge in order to comprehend the financial matters that the ACs discuss or investigate. Positive relationship between members' financial knowledge and ACs effectiveness particularly their potentials to ensure a good quality financial reporting process and compliance of related rules have been found in many studies. Previous research has provided plenty of evidence of the importance of ACFE in constraining EM practices. DeZoort \& Salterio (2001) contend that the financial knowledge of AC's members increases the chance to identify material misstatements and to correct them at appropriate times. Moreover, Felo et al. (2003) reports a significant positive relationship between the proportion of $\mathrm{AC}$ members having financial expertise and the quality of financial reporting in terms of enhancing the financial reporting quality. Additionally, Xie et al. (2003) document that ACs that include directors with sufficient knowledge in corporate financials are more effective in reducing EM. Saleh et al. (2007) provide evidence indicative of mitigation of EM practices in companies whose AC members are characterized with financial knowledge and experience, and professionalism when compared to other companies in Malaysian firms. Similar results are also confirmed in the Egyptian context by Soliman \& Ragab (2014) and by Elijah \& Ayemere (2015) in Nigerian firms, in Sri Lankan by Kankanamge (2016), and in US by Zalata et al. (2018).

The empirical evidence and the regulatory bodies in Jordan recommend that to enhance the AC's decisions and performance the possession of the appropriate knowledge and understanding, largely in auditing and accounting is required. The Jordanian Corporate Governance Code of 2009 (JCGC) calls for all the ACs to hire one or more $\mathrm{AC}$ members with the appropriate and current financial knowledge. Therefore, an AC that has a high ratio of financial expertise is probable to constrain EM in Jordan. This has been documented by Hamdan et al. (2013) who state that the ACFE, among other characteristics of ACs of firms listed on ASE, improves the quality of reported earnings through constraining EM practices.

Despite the conclusive evidence of the effectiveness of ACFE in deterring EM practices, previous research suggests that the effectiveness of monitoring mechanisms is much influenced by the type of ownership structure (Chobpichien et al., 2008). Abdullatif et al. (2015) find similar evidence suggestive of limiting the performance of ACs' duties by the dominance of family ownership in Jordan.

Within the context of EM, Richardson (2000) reports that agency conflicts within a firm are considered as an influential source of EM activities in emerging markets with highly concentrated ownership. In such markets, the agency conflict exists normally between the conflicting interests of the controlling and minority shareholders instead of the conflict being between the company owners and the executives in dispersed ownership contexts. Nevertheless, the agency conflicts are very severe in the companies owned by families because the owners might have both the capability and a motivation to get individual benefits meant for the minority stockholders through increasing the level of the EM practices. Accordingly, while there is a consensus concerning the effectiveness of ACFE in constraining EM practices, it seems that the AC effectiveness could be affected by FOC in the sense that $\mathrm{AC}$ can become less effective in mitigating EM.

To the best of the researchers' knowledge, no research so far has examined the effect of the inclusion of FOC on the association between ACFE and EM. To do so, this research introduces FOC as the moderator variable on the relationship between ACFE and EM because the ownership of the controlling family in Jordan is extensive and the law is feeble at protecting the minority stockholders (Al-Najjar, 2010). Hence, the current study suggests the hypothesis below in order to test this anticipation:

H1: FOC weakens the association between ACFE and EM. 


\section{Research Methodology}

\subsection{Sample Selection}

The sample consists of all manufacturing firms are listed on ASE, where family ownership is more common at manufacturing and financial companies (Al-Najjar, 2010). This research excludes financial firms from the sample because of differences in regulatory requirements. As of December 31, 2016, a total of 68 firms were listed on the ASE. Data are collected for all of the 68 firms for a recent five-year time period, from 2012 to 2016.

The base data of financial and non-financial information come from the ASE website (www.ase.com.jo), which has annual reports of industrial listed firms in Jordan. Annual reports for a (3) firms were not available for all the years as some firms were listed after 2012, and (5) firms got delisted during the 2012-2016 time period. Therefore, a list-wise removal of cases that missed the values led to the ultimate sample that comprised 300 firm-year observations of 60 firms.

\section{Regression Model}

The current research uses two regression models in order to test its hypothesis as follows: First, the relationship between ACFE and EM is evaluated in the model (1). Second, the model (2) is employed to measure the impact of FOC on the relationship between ACFE and EM through the inclusion of an interaction term between ACFE and FOC.

Model (1): $\quad$ ADAit $=a 0+\beta 1$ ACFEit $+\beta 2$ SIZit $+\beta 3$ LVit $+\beta 4$ GROit $+\varepsilon i t$

Model (2): $\quad$ ADAit $=a 0+\beta 1$ ACFEit $+\beta 2$ SIZit $+\beta 3$ LVit $+\beta 4$ GROit $+\beta 5$ FOCit $+\beta 6$ ACFEit $*$ FOCit $+\varepsilon i t$

Table 1 provides a detailed summary of the definition of the above variables.

Table 1. Measurements of the Variables

\begin{tabular}{lll}
\hline Variables & Symbol & Measurement \\
\hline $\begin{array}{l}\text { Dependent Variable: } \\
\text { Earnings management }\end{array}$ & ADA & $\begin{array}{l}\text { The discretionary accruals estimated by the Kothari et al. (2005) } \\
\text { model. }\end{array}$ \\
$\begin{array}{l}\text { Independent variables: } \\
\text { Audit Committee Financial Expertise }\end{array}$ & ACFE & $\begin{array}{l}\text { Percentage of audit committee members with financial expertise to } \\
\text { total members. }\end{array}$ \\
$\begin{array}{l}\text { Control variables: } \\
\text { Firm size }\end{array}$ & SIZ & Natural logarithm of total assets. \\
$\begin{array}{l}\text { Firm leverage } \\
\text { Firm Growth }\end{array}$ & LV & $\begin{array}{l}\text { Total liabilities scaled by total assets. } \\
\text { Moderator variable: }\end{array}$ \\
$\begin{array}{l}\text { Family ownership control } \\
\text { ThO change in total assets scaled by lagged total assets. }\end{array}$ \\
\hline
\end{tabular}

\section{Dependent Variable}

In line with previous research, this research uses discretionary accruals to measure EM. Many prior studies employ Kothari et al. (2005) model because this model proved by a set of statistical tests that the performance-matched discretionary accruals model is most robust to detect EM. This model is shown below:

$$
\boldsymbol{T} \boldsymbol{A} \boldsymbol{C}_{i t} \boldsymbol{T} \boldsymbol{A}_{i t}=\alpha\left(1 / T A_{i t-1}\right)+\beta_{1}\left(\left(\Delta R E V_{i t}-\Delta R E C_{i t}\right) / T A_{i t-1}\right)+\beta_{2}\left(P P E_{i t} T A_{i t-1}\right)+\beta_{3} R O A_{i t-1}+\varepsilon_{i t}
$$

Where;

$T A C_{i t}=$ Total accruals of the firm.

$T A_{i t-1}=$ Total assets in year $t-1$.

$\triangle R E V_{i t}=$ Change in revenues of the firm.

$\triangle R E C=$ Change in accounts receivable in year t from year t-1 for company $i$.

$P P E_{i t}=$ Property, plant and equipment of the firm. 
$R O A_{i t-1}=$ Return of assets of the firm in year $t-1$.

$\alpha \beta_{1} \beta_{2} \beta_{3}=$ Estimated parameters.

$\varepsilon_{i t}=$ The residual.

\section{Independent variables}

The Independent variables include $\mathrm{ACFE}$ as a predictor variable, FOC as moderate variable, and the interaction term between ACFE and FOC. ACFE is measured by the ratio of AC members with financial or accounting expertise to total number of committee members (Goh, 2009). The financial and accounting knowledge is necessary to the members of the AC because the key task of the members is to make sure that there is integrity in financial reporting.

FOC is the ratio of family members to total number of directors on the board (Hashim, 2011). Prior studies find that FOC has a moderating influence on the association between board independence, AC independence, and EM (e.g., Jaggi et al., 2009; Idris et al., 2018a).

Following prior studies above, to detect moderator effect, the interaction variable (ACFE * FOC) is computed by multiplying ACFE (i.e. the predictor variable) with FOC (i.e. the moderator variable).

\section{Results and Discussion}

\subsection{Descriptive Statistics}

The research presents the descriptive statistics of the current study's variables in Table 2 below. ADA's mean is 0.214 , and its minimum value is 0.006 while the maximum value is 0.596 . ACFE's mean is $39.2 \%$ showing that around $39.2 \%$ of the ACs in current study meets what the JCGC needs of possessing one or more financial professionals in the ACs' membership. This finding is in line with the prior Jordan research such as that of Hamdan et al. (2013) who reports that ACFE has a value of 40\% in industrial firms listed on ASE. However, the zero (0) minimum value for the ACFE indicates that some firms in this study breached the rules. In addition, the findings in Table 2 show that FOC differs from $0 \%$ to $100 \%$, with a median and standard deviation $33.8 \%$ and $23.6 \%$, respectively.

Table 2. Descriptive statistics

\begin{tabular}{lllll}
\hline Variable & Mean & Std. Dev. & Max. & Min. \\
\hline ADA & 0.214 & 0.083 & 0.596 & 0.006 \\
ACFE & 0.392 & 0.233 & 0.750 & 0.000 \\
FOC & 0.338 & 0.236 & 1.000 & 0.000 \\
SIZ & 7.217 & 0.485 & 8.103 & 5.860 \\
LV & 0.383 & 0.263 & 1.796 & 0.003 \\
GRO & 0.012 & 0.191 & -0.541 & 1.143 \\
\hline
\end{tabular}

In addition, the table indicates the descriptive statistics for SIZ, LV, and GRO, which are the control variables that the researcher uses in the current study. From the table, SIZ's mean is 7.217, which is consistent with the previous studies in Jordan such as that of Idris et al. (2018b). The LV's mean for the companies in the sample is $38 \%$. This finding is in line with Al-Fayoumi et al. (2010) for all industrial listed firms on ASE. Finally, growth ratio has an average 0.012 with a standard deviation 0.191 . 


\subsection{Main Empirical Results}

Table 3. Regression Analysis of ACFE, EM and FOC

\begin{tabular}{lllll}
\hline & \multicolumn{3}{l}{ Model (1) } & \multicolumn{2}{l}{ Model (2) } \\
& Cofe. & $t$-stat & Cofe. & $t$-stat \\
Intercept & $0.233^{* * *}$ & 13.347 & $0.239^{* * *}$ & 12.237 \\
ACFE & $-0.054^{* *}$ & -2.074 & $-0.086^{* *}$ & -2.045 \\
FOC & & & $-0.077^{*}$ & -1.785 \\
ACFE * FOC & & & $0.234^{* *}$ & 2.239 \\
SIZ & $0.000^{* *}$ & -2.355 & $0.000^{* * *}$ & -2.745 \\
LV & $0.001^{* * *}$ & 2.395 & $0.000^{* *}$ & 2.356 \\
GRO & 0.005 & 0.148 & 0.033 & 1.121 \\
Adj.R & 0.054 & & 0.052 & \\
Obs & 220 & & 220 & \\
F-stat & 2.532 & & 2.974 & \\
\hline
\end{tabular}

***, $* *$ and * indicate significance at $1 \%, 5 \%$ and $10 \%$ respectively. Refer to table 1 for explanation of variables details except for ACFE * FOC which equals the interaction between audit committee financial expertise and family ownership control.

The statistical findings of this research are shown in Table 3, where this research finds a significant and inverse relationship between the ACFE and EM. This relationship indicates that when the AC has a financial professional, he or she plays a vital duty of assuming the monitoring responsibility of the committee, hence, decreasing the EM practices. The result is consistent with the theory, which calls for all the ACs to hire one or more AC members with the appropriate and current financial knowledge in order to monitor the quality of financial reports. This result supports the previous studies evidence of a negative relationship between ACFE and EM (e.g., Elijah \& Ayemere 2015). Overall, a stream of literature on AC characteristics and EM consider ACFE as one of the most crucial characteristics in an AC's effectiveness which is lead to reduce EM incidence (Abbott et al., 2004). Therefore, the JCGC requires the ACs to hire one or more AC members with the appropriate and current financial knowledge in order to monitor the quality of financial reports.

Furthermore, this research also focuses on testing the impact of FOC on the relationship between ACFE and EM. As apparent in Table 3, the interaction between FOC and the ACFE is statistically significant and positive. This means that the relationship between the ACFE and EM becomes weak when the controlling family ownership in firm exists. This finding is extends the study of Abdullatif et al. (2015) through documenting that the effectiveness of ACs in preventing EM is lower the Jordanian context where family business model prevails.

Given the above discussion, the findings of this research is in line with expectation of agency theory which suggests that family-controlled firms will have less demand for an effective AC than in non-family-controlled due to the family firms want to take advantage of minority shareholders, especially in Jordan which is characterized mainly by a high concentration of ownership (FOC) and legal protection of minority shareholders is weak (Al-Fayoumi et al., 2010).

\section{Conclusion}

The current study examines the impact of ACFE on EM using data from a sample of industrial Jordanian companies from 2012 to 2016. In addition, it investigates whether FOC affects the relationship between ACFE and EM. The results of this study document that ACFE is effective monitoring mechanism in reducing the level of EM. This means that the existence of financial expert members on AC prevents managements from engaging in EM practices and thus protecting the interests of the shareholders. Furthermore, the effectiveness of ACFE is lower in family-controlled firms, and an increase in the number of AC members' who has financial expertise is unlikely to be effective in restricting EM practices in family-controlled firms. A possible interpretation of this result is that the role of ACFE is less effective in reducing EM when the family ownership increases.

The current research contains a number of limitations. First, this research focuses only on industrial listed firms on ASE and ignores any other types of listed firms, thus, the findings of the study may not be applicable to other sectors. Second, other variables that may affect EM are not examine in this study such as AC independence or other types of ownership such as foreign and institutional ownerships.

The results of this study should be of interest to shareholders, regulators and policy makers, especially issues relative to the relationship between corporate governance mechanisms and EM practices. The results may help policy makers and regulators to make any changes deemed necessary to improve good governance practices and attempt to constrain the incidence of EM in Jordan. 


\section{References}

Abbott, L. J., Parker, S., \& Peters, G. F. (2004). Audit Committee Characteristics and Restatements. Auditing: Journal of Practice and Theory, 23(1), 69-89.

Abdullatif, M., Ghanayem, H., Amin, R., Al-Shelleh, S., \& Sharaiha, L. (2015). The Performance of Audit Committees in Jordanian Public Listed Companies. Corporate Ownership and Control, 13(1), 1-21.

Agrawal, A., \& Chadha, S. (2005). Corporate Governance and Accounting Scandals. Journal of Law and Economics, 48(2), 371-406.

Al-Fayoumi, N., Abuzayed, B., \& Alexander, D. (2010). Ownership Structure and Earnings Management in Emerging Markets: The Case of Jordan. International Research Journal of Finance and Economics, 38, 28-47.

Al-Najjar, B. (2010). Corporate Governance and Institutional Ownership: Evidence from Jordan. Corporate Governance, 10(2), 176-190.

Amman Stock Exchange. (2017). Retrieved from: http://www.ase.com.jo/en/about-ase

Arun, T. G., Almahrog, Y. E., \& Aribi, Z. A. (2015). Female directors and earnings management: Evidence from UK companies. International Review of Financial Analysis, 39, 137-146.

Cadbury Committee Report. (1992). The Financial Aspects of Corporate Governance. Gee and Co. Ltd. London.

Chen, S., \& Komal, B. (2018). Audit committee financial expertise and earnings quality: A meta-analysis. Journal of Business Research, 84, 253-270.

Chobpichien, J., Haron, H., \& Ibrahim, D. (2008). The Quality of Board of Directors, Ownership Structure and Level of Voluntary Disclosure of Listed Companies in Thailand. Euro Asia Journal of Management, 3(17), 3-39.

DeZoort, F. T., \& Salterio, S. E. (2001). The Effects of Corporate Governance Experience and Financial Reporting and audit Knowledge on Audit Committee Members' Judgments. Auditing: A journal of Practice and Theory, 20(2), 31-47.

Elijah, A., \& Ayemere, I. L. (2015). Audit Committee Attributes and Earnings Management: Evidence from Nigeria. International Journal of Business and Social Research, 5(4), 14-23.

Felo, A. J., Krishnamurthy, S., \& Solieri, S. A. (2003). Audit Committee Characteristics and the Perceived Quality of Financial Reporting: An Empirical Analysis. Available at SSRN 401240.

Goh, W. (2009). Audit Committees, Boards of Directors, and Remediation of Material Weaknesses in Internal Control. Contemporary Accounting Research, 26(2), 486-508.

Hamdan, A. M. M., Mushtaha, S. M. S., \& Al-Sartawi, A. A. M. (2013). The Audit Committee Characteristics and Earnings Quality: Evidence from Jordan. Australasian Accounting, Business and Finance Journal, 7(4), 51-80.

Hashim, H. A. (2011). The Board of Directors in Family Controlled firms. 1st International Conference on Accounting, Business and Economics. University Malaysia Terengganu.

Idris, M. I. I. (2012). The Impact of Ownership Structure and External Audit on Accruals and Real Activities Earnings Management in Jordan. Published PhD thesis, University of Gloucestershire, UK.

Idris, M., Siam, Y. A., \& Nassar, M. (2018a). Board independence, earnings management and the moderating effect of family ownership in Jordan. Management \& Marketing, 13(2), 985-994.

Idris, M., Siam, Y. A., \& Ahmad, A. (2018b). The impact of external auditor size on the relationship between audit committee effectiveness and earnings management. Investment Management and Financial Innovations, 15(3), 122-130.

Jaggi, B., Leung, S., \& Gul, F. (2009). Family Control, Board Independence and Earnings Management: Evidence Based on Hong Kong Firms. Journal of Accounting and Public Policy, 28(4), 281-300.

JCGC, Corporate Governance Code for Shareholding Companies Listed on the Amman Stock Exchange, 2009. Retrieved from http://www.jsc.gov.jo/Public/english.aspx?Lang=1andPage_Id=225andMenuID2=257

Kankanamge, C. (2016). Relationship between audit committee characteristics and earnings Management in Sri Lanka (2013-2015). Sri Lanka Institute of Information Technology.

Kothari, S. P., Leone, A. J., \& Wasley, C. E. (2005). Performance-Matched Discretionary Accruals. Journal of 
Accounting and Economics, 39(1), 163-197.

Lin, P. T., Hutchinson, M. R., \& Percy, M. (2009). The Role of the Audit Committee and Institutional Investors in Constraining Earnings Management: Evidence from Chinese Firms Listed in Hong Kong. In Proceedings of Accounting and Finance Association of Australia and New Zealand Annual Conference 2009. Accounting and Finance Association of Australia and New Zealand (AFAANZ).

Porta, R., Lopez-de-Silanes, F., \& Shleifer, A. (1999). Corporate Ownership around the World. The Journal of Finance, 54(2), 471-517.

Rezaee, Z. (2005). Causes, Consequences, and Deterrence of Financial Statement Fraud. Critical Perspectives on Accounting, 16(3), 277-298.

Richardson, V. J. (2000). Information Asymmetry and Earnings Management: Some Evidence. Review of Quantitative Finance and Accounting, 15(4), 325-347.

Saleh, N. M., Iskandar, T. M., \& Rahmat, M. M. (2007). Audit Committee Characteristics and Earnings Management: Evidence from Malaysia. Asian Review of Accounting, 15(2), 147-163.

Siam, Y. A., Laili, N. H., \& Khairi, K. F. (2015). The Relationship between audit committee characteristics and earnings management among Jordanian listed companies: Proposing conceptual framework. Research Journal of Finance and Accounting, 6(18), 2-10.

Soliman, M. M., \& Ragab, A. A. (2014). Audit Committee Effectiveness, Audit Quality and Earnings Management: An Empirical Study of the Listed Companies in Egypt. Research Journal of Finance and Accounting, 5(2), 155-166.

Wang, D. (2006). Founding Family Ownership and Earnings Quality. Journal of Accounting Research, 44(3), 619-656.

Xie, B., Davidson III, W. N., \& DaDalt, P. J. (2003). Earnings Management and Corporate Governance: The Role of the Board and the Audit Committee. Journal of Corporate Finance, 9(3), 295-316.

Zalata, A. M., Tauringana, V., \& Tingbani, I. (2018). Audit committee financial expertise, gender, and earnings management: Does gender of the financial expert matter? International Review of Financial Analysis, 55, $170-183$

\section{Copyrights}

Copyright for this article is retained by the author(s), with first publication rights granted to the journal.

This is an open-access article distributed under the terms and conditions of the Creative Commons Attribution license (http://creativecommons.org/licenses/by/4.0/). 